\title{
Exploring the Useful Reading Strategies among EFL College Students in Taiwan
}

\author{
Kung Shan-Shan \\ Department of English Studies, MingDao University, Changhua, Taiwan, China \\ Email: san00720@hotmail.com
}

Received August 22 ${ }^{\text {nd }}, 2013$; revised September 23 ${ }^{\text {rd }}, 2013$; accepted October $2^{\text {nd }}, 2013$

\begin{abstract}
Copyright (c) 2013 Kung Shan-Shan. This is an open access article distributed under the Creative Commons Attribution License, which permits unrestricted use, distribution, and reproduction in any medium, provided the original work is properly cited.
\end{abstract}

\begin{abstract}
The major purpose of this study was to understand what the reading strategies the EFL students use more or less among EFL college students in Taiwan. The study focused on three hundred and ninety-eight EFL college students coming from seven colleges located in the north, central, and south Taiwan. The research instrument was a questionnaire modified from Wan-Yin Lin's Chinese reading strategies questionnaire (2005). The collected data used the Statistical Package for the Social Sciences (SPSS) version 13.0 to analyze the results. The findings of study included the following: first, higher grade students had more variety in using reading strategies than lower grade students; and second, the higher grade students tended to use integrated strategies more than lower grade students. According to the research findings, the researcher provided some recommendations, such as teachers could be better guiders to help students understand the importance of reading in language learning. They can not just focus on teaching listening and speaking, and should enhance the balance development in integrated reading strategies that helped students could read fluently any English materials.
\end{abstract}

Keywords: Reading Strategies; EFL Students; Integrated Strategies

\section{Introduction}

From junior high to senior high, students usually learn the four English skills of speaking, listening, reading, and writing step-by-step. Recently, the situation has changed. More and more teachers would like to focus on the teaching of speaking and listening in English to match the globalized world trend and the needs of business. However, Pauston and Bruder (1976) reported that when people learned the four skills of speaking, listening, reading, and writing in a second language, reading was usually the skill that English as Foreign Language (EFL) students really wanted to learn and acquire. Therefore, the study focused on exploring the use of reading strategies among EFL college students in Taiwan and examined which reading strategies students usually used or did not use for understanding the English materials. All the information gathered from this study helped teachers of EFL students understand the instructional implications found within literacy development. The following questions guided this study:

1) Did Taiwanese EFL college students use reading strategies to help them read? If so, what reading strategies did they use more for helping them understand contents?

2) What reading strategies did they use less than others, or never use during the reading process?

There were four reasons to show that this study was significant. First, the research could help students be aware of what their reading behaviors were and of what reading strategies they used most or least when they read English materials. Students could try to think about whether they could have made some

*Short paper. changes to their reading behaviors or could have enhanced the use of reading strategies. Second, the results of the study provided information to students about the strategies that other students used when they read English materials. Through the transference of information, the students could learn about good reading strategies they could use to help them to get the main points from the reading texts. Third, the study provided some information to the teachers to help them understand their students' reading behaviors and the reading strategies they used. When teachers understood students' reading processes, they could try to adjust their teaching skills to help students to read easier.

According to students' reading situations, teachers could arrange the appropriate teaching materials for students. Finally, the study could be used as a reference for further research to help future researchers know what recent students' reading situations were and let them focus on the students' weaknesses to provide more useful suggestions and teaching strategies for helping those students who had reading difficulties in English. Through this study, the researcher expected that the EFL students, teachers, and further researchers could get some useful information to understand what the reading process for Taiwan's EFL college students should include and to provide some good suggestions for further studies in the field of reading.

\section{Literature Review}

Some researchers as Nuttall (1982) and Casanave (1988) pointed out that reading was a process with which readers actively used some strategies to work with the meaning of the 
texts and then made sense from them. By the interesting interactions from the readers and texts, more and more researchers keep working with studies about the relationship between reading comprehension and the use of reading strategies.

However, when talking about strategy and skill, it was apparent that they were different. Strategy meant people used planned methods and actions to achieve their goals, but skill was a routine and reflex behavior. Because strategy was a conscious, specific, and integral planning, readers could use it to handle different reading materials (Dole et al., 1991). Besides, strategy was the result of consciously working toward goals. It helped readers to understand the meaning of contents to find out answers or attain a certain performance level in reading that they want for themselves (Gagné, 1985).Pearson and Fielding (1991) summarized what happened during their version of strategic reading:

"Students understand and remember ideas better when they have to transform those ideas from one form to another. Apparently it is in this transformation process that the author's ideas become [the] reader's ideas, rendering them more memorable. Examined from the teacher's perspective, what this means is that teachers have many options to choose from when they try to engage students more actively in their own comprehension: summarizing, monitoring, engaging visual representation, and requiring students to ask their own questions all seem to generate learning” (p. 847).

Besides, Perkins (1992) also had a statement to suggest teachers had to tell students the important ideas on both benefits of requiring and using cognitive strategies:

"Complex cognition has more intrinsic interest and promises more payoff outside of school and later in life. But consider the cost to learners: complex cognition demands much more effort. It creates greater risk of failure. It introduces the discomforts of disorientation, as learners struggle to get their heads around difficult ideas. Peer status for complex cognition is certainly mixed; who wants to be known as a 'brain'? And very commonly, so far as grades and teacher approval go, complex cognition buys no more than the simpler path of getting facts straight and the algorithms right. No wonder, then, that students perfectly reasonably do not automatically gravitate toward complex cognition” (pp. 59-60).

Oxford (1992-1993) stated that students would like to use their preferred strategies which reflected their learning styles. For example, students in an analyzing learning style would like to prefer a strategy such as rule-learning, while students with global learning style would prefer to use strategies to find out their picture (i.e., scanning, predicting) and help them to understand the contents without knowing all the words (i.e., gesturing). When mentioning reading strategy, different researchers used different aspects to discuss it. Based on the other related researches, the types of reading strategies could be classified by their reading processes, characters, and functions. In some reading teaching researches (Gagné, 1985; Vacca, 1981; Vacca \& Vacca, 1986), they divided the use of reading strategies into three processes of before reading, during reading, and after reading. Before reading, readers might use cues from the title of article, or predict the contents to establish the interest to read the articles. During reading, readers might choose the main points to read or understand the relationship between sentences to help them understand the contents. After reading, readers might review the main points or summarize for the contents to know if they understand what they read.

Some researchers (Bock, 1993; Keene \& Zimmermann, 1997; El-Koumy, 2004) mentioned that reading strategies can be divided into cognitive and metacognitive styles. Cognitive strategy meant readers had interaction with contents by using strategies to help them understand the contents. Cognitive strategies included visualizing, predicting, scanning, summarizing, analyzing, making connection, underlining, and using mnemonics, etc. El-Koumy (2004) stated that, "Metacognitive strategy-often referred to as self-regulation strategies-refers to the reader's knowledge about the executive processes he or she employs before, during, and after reading” (p. 16). They mentioned there were three main strategies in this area: planning, self-monitoring, and self-assessment. Dutta (as cited in ElKoumy, 2004) described that planning was used by readers to make a comprehensive plan to understand the contents. Glazer (as cited in El-Koumy, 2004) indicated that, "self monitoring-or comprehension monitoring as it is often called-refers to the readers' regulation of his or her own comprehension during reading” (p. 19). Schunk (1997) mentioned that metacognitive strategy helped students check and adjust their reading strategies for failure comprehension. Shoemaker (as cited in ElKoumy, 2004) described self-assessment helped readers to monitor and adjust their strategic thinking in literacy learning.

According to the reading styles that Carrell (1989) mentioned, he divided reading strategies into repair, effective, and confident strategies. Repair strategy helped readers to understand the contents when they did not have strong language ability, such as using the context or the meaning of the sentence to solve their vocabulary problem when they faced a new word during their reading process. Effective strategy meant readers used some strategies to help them read effectively during their reading process, such as asking someone, taking notes, highlighting, and summarizing, etc. Confident strategy helped readers to decrease their fearfulness or increase their interest to read, including reviewing the article, predicting the contents, and overview the table of contents. These strategies could help readers to get new information and combine their own knowledge to promote the understanding and memorizing of contents. Therefore, the use of effective strategies could help readers think and assist them to know how and when to solve their reading problems by their own knowledge (Pressley et al., 1989).

Carter \& McGinnis (1967) described that the purpose of reading is to gain the enjoyment and information from written language. Reading is a developmental process in both of thinking and learning. It is an important way to communicate with others and can be developed throughout life. Learning to read is influenced by the individual's level of physical and psychological development and is influenced by one's surrounding. Reading needed more than the accumulation from different skills. It is a manifestation of the whole personality of the reader and his behavior. Reading was a meaningful activity to find out, and explain the ideas from the writers. Therefore, this meant that reading was a complex language skill that could not be focused on a certain way in order to develop it.

When people read a text, they usually attempted to understand the meaning of what they read by using the visual clues of spelling, experience or background knowledge. Reading was an active process, so readers must use their various abilities that 
they have already acquired to interact with the authors' texts and then got main ideas or knowledge from them. These abilities were usually varied. Wardhaugh (1969) figured out that readers were usually able to react to the significant visual hints, not the nonsignificant visual ones. This meant that readers needed to use their short or long-term memories effectively during the reading process. Reading was a different kind of linguistic performance than listening as listening was different than speaking. Reading materials were usually more difficult than, for example, a spoken presentation; written language was more complex, cautious, less redundant and edited than spoken language. Therefore, the teaching of reading must be focused on the total language program that reading played as an important part. The program must emphasize how language was used rather than how it should be used. Language in its all different forms was useful for study and could provide various meaningful experiences to students in all ages, so matching the total language learning with the students' learning abilities could help students to develop reading ability more easily (Wardhaugh, 1969).

\section{Methods and Procedures}

\section{Instrumentation}

The study used one questionnaire to explore the use of reading strategies among EFL college students in Taiwan. The questionnaire was based on a sample of the Chinese reading strategy questionnaire from Wan-Yin Lin (2005). After modifying and translating to English, it was used as the format for the study. When students completed the questionnaire in Taiwan, they used the modified Chinese version which was translated from the English edition.

\section{Selection of the Participants}

The participants were selected from seven colleges located in north, central and south of Taiwan. A total of five hundred and nine students were from Taipei City, Taipei County, Hsinchu City, Taichung County, Tainan City, and Kaohsiung City, participated in this research study. They volunteered to fill out the questionnaire. The five hundred and nine students were chosen from academic standings in the colleges. These students were not English majors but they were still required to take some English courses.

\section{Response Rate}

The EFL students $(\mathrm{N}=509)$ were selected from seven colleges which were located in north, central, and south Taiwan. However, 111 students did not complete all the questions or provided unclear answers or left some of blanks. Therefore, 398 questionnaires were completed and returned. 398 questionnaires were analyzed for the purpose of this study. The actual response rate was $78.19 \%$.

\section{Results}

The following findings were discovered through descriptive statistical procedures to find out the correlations between the mean scores for the results from the answers for each research question. The following findings emerged:

1) In the first reading situation "when I read English material", strategy 2 "I focus on the first sentence of each paragraph for helping me understand the main points of the whole paragraph", strategy 5 "I write Chinese annotation on the margin for vocabulary words I don't understand during reading”, and strategy 7 "I predict the contents' main points through the articles" were most used by the most freshmen, sophomore, junior, and senior students. As for strategy 4 "I write down the key points on the paper or the margin of each paragraph" and strategy 6 "I read the first and last paragraphs, and then go back to reread the paragraphs” were the strategies most students used least.

2) In the second reading situation "during reading process", the strategy 9 "I use life experiences helping me understand the meanings of texts", strategy 12 "I use key words or sentences to guess the main idea of the articles", and strategy 13 "I guess the main idea of articles through illustrations" were the most popular strategies which most participants would use to help them comprehend the reading contents. Strategy 11 "I use the background knowledge of the English culture to understand the contents" and strategy 16 "I discuss what I read with classmates" were the strategies that most participants used least.

3) In the third reading situation "When I do not understand a vocabulary", most participants would like to use strategy 19 "I use other words in the sentence to infer the meaning of vocabulary" to solve their vocabulary problems during reading process. As for strategy 20 "I use its pronunciation to perceive its meaning" and strategy 21 "I analyze its suffix and prefix to get its meaning” were the two strategies that most participants did not use.

4) In the reading situation of "when I do not understand a sentence", most participants liked to use strategy 22 "I use the context (topic, subject) to derive the meaning of each sentence" to help them understand the meaning of a sentence. Strategy 24 "I take grammar analysis (ex: finding subject and verb etc.) to understand the meaning of sentences" and strategy 25 "I analyze the structure of sentences (ex: sample sentence, adjective clause, or adverb clause etc.) to derive at the meaning of sentence" were least used by the most participants to solve their sentence problems during their reading process.

5) In the reading situation of "when I don't understand (including vocabulary and sentences), except above reading strategies", the strategy 30 "I decrease my reading speed" and strategy 31 "I read the difficult parts several times" were the more popular strategies used by the participants. As for the strategy 34 "I will memorize the vocabulary pertaining to the contents before reading”, most participants used it less to help them understand the contents.

\section{Conclusion}

The purpose of this study was to investigate the use of reading strategies among EFL college students in Taiwan. Through the research findings, the study found that most students, including those with fewer learning experiences, would choose appropriate reading strategies to help them read fluently and effectively when they met the reading problems during their reading process.

The study has presented a lot of information about the use of reading strategies among EFL college students in Taiwan. Although the study was limited by three hundred and ninety-eight students coming from seven colleges located in the parts of north, central, and south Taiwan, the findings may be used to predict the possible Taiwanese EFL students' viewpoints of 
learning in reading. The results of this study may become a valuable reference for further research in teaching reading; for this reason, several recommendations made from the finding and conclusion were listed below.

1) Teachers should teach integrated strategies to the students, not just focus on teaching cognitive or metacognitive strategies. The strategies such as compensation, memory, social, and affective strategies should be taught to help students understand the whole shape of strategies (Oxford, 1992/1993).

2) Because some strategies that were less often or never heard about by the students were used, teachers should have a responsibility to teach those useful strategies to students to help them understand what they read and enjoy in the reading process.

3) Future studies can investigate if teaching particular reading strategies results in better reading scores on standardized tests.

\section{REFERENCES}

Bock, S. (1993). Developing materials for the study of literature. English Teaching Forum, 31, 3-9.

Carter, H. L. J., \& McGinnis, D. J. (1967). Reading: A key to academic success. Dubuque, IA: WM. C. Brown Company Publishers.

Casanave, C. P. (1988). Comprehension monitoring in ESL reading: A neglected essential. TESOL Quarterly, 22, 282-302. http://dx.doi.org/10.2307/3586937

Dole, J. A., Duffy, G. G., Roehler, L. R., \& Pearson, P. D. (1991). Moving from the old to new: Research on reading comprehension instruction. Review of Educational Research, 61, 239-264.

El-Koumy, A. S. A. K. (2004). Metacognition and reading comprehension: Current trends in theory and research. ERIC Document No. ED 490569, Washington, DC: American Educational Research Association.
Gagné, E. D. (1985). The cognitive psychology of school learning. Boston, MA: Little, Brown and Company.

Keene, E., \& Zimmermann, S. (1997). Mosaic of Thought: Teaching Comprehension in a Reader's Workshop. Portsmouth, NH: Heinemann.

Lin, W. Y. (2005). Investigating Taiwanese Spanish learners' metacognitive awareness in reading: A case study of Spanish students at Providence University in Taiwan. Unpublished Master Dissertation, Taichung: Providence University.

Nuttall, C. (1982). Teaching reading skills in a foreign language. London: Richard Clay Ltd, Bungay, Suffolk.

Oxford, R. L. (1992/1993). Language learning strategies in nutshell: Update and ESL suggestions. TESOL Journal, 2, 18-22.

Paulson, C. B., \& Bruder, M. N. (1976). Teaching English as a second language: Techniques and procedures. Cambridge, MA: Winthrop Publishers, Inc.

Pearson, P. D., \& Fielding, L. (1991). Comprehension instruction. In R. Barr, M. L. Kamil, P. B. Mosenthal, \& P. D. Pearson (Eds.). Handbook of reading research (Vol. 2, pp. 815-860). New York: Longman.

Perkins, D. N. (1992). Smart schools: Better thinking and learning for every child. New York: Free Press.

Pressley, M., Johnson, C. J., Symons, S., McGoldrick, J. A., \& Kurita, J. A. (1989). Strategies that improve children's memory and comprehension of text. The Elementary School Journal, 90, 3-32. http://dx.doi.org/10.1086/461599

Schunk, D. (1997). Self-monitoring as a motivator during instruction with elementary school students. ERIC Document No. ED 404035, Washington, DC: American Educational Research Association.

Vacca, R. T. (1981). Content area reading. Boston, MA: Little, Brown and Company.

Vacca, R. T., \& Vacca, J. A. L. (1986). Content area reading. Boston, MA: Little, Brown Company.

Wardhaugh, R. (1969). Reading: A linguistic perspective. United States of America: Harcourt, Brace \& World, Inc. 